\title{
CORRESPONDENCE
}

\section{PRECAMBRIAN PERTHOSITES IN NYASALAND}

SIR,- In his recent article on Pre-Cambrian perthosites of Nyasaland (Geol. Mag., 98, 235-245), Dr. S. W. Morel evidently deals with a series of rocks showing an evolution of the perthites, which has not received proper recognition. The evolution could perhaps be demonstrated from the rocks formed solely of perthites-through rocks formed of perthites with marginal oligoclase (in optical and crystallographic continuity with the plagioclase component of perthite, p. 241), to rocks formed of perthites "separated from one another by a narrow zone of granulitic oligoclase" (i.e. discrete grains of oligoclase). The apparently "perthite free" types may evolve from complete replacement of perthite. The transitional stages of replacement are marked by relict "wisps of antiperthites" in oligoclase. The particular observation that " the amount of oligoclase present varies with the amount of perthite" signifies a genetic connection between the two. Such trends of textural evolution of perthites have long ago been discussed and demonstrated by Tuttle (1952). The development of sodi-potassic felspar (from corresponding late liquid) in the rocks was very likely mostly post-kinematic, as hinted by the author (p. 241). Igneous action thus partly post-dates metamorphism in the region studied.

Perthosites of Koraput, India, have many features in common with those of Nyasaland and are formed of perthites with crenulated margins, due to development of secondary albite. The exsolving albite shows a tendency to come out of the host and to localize along the periphery of grains. The feature is, however, well marked in the associated nepheline syenites.

\section{Department of Geology, \\ Presidency College, Calcutta. \\ 15th August, 1961.}

MiHir K. Bose.

\section{REFERENCES}

Morel, S. W., 1961. Pre-Cambrian Perthosites in Nyasaland. Geol. Mag., 98, 234-245.

TUtTLE, O. F., 1952. The origin of contrasting mineralogy of extrusive and plutonic salic rocks. J. Geol., 60, 107-124.

\section{ORIGIN OF ALBITE PORPHYROBLASTS}

SiR,--Dr. Trendall, in his letter to the Geological Magazine (98, 263-4), considers that $I$ have misrepresented his conclusions concerning albite gneisses to an extent worth correcting. My purpose in quoting Dr. Trendall was not to be critical, but to give his work precedence and acknowledgment. It does seem that I have misunderstood him at one point, but I cannot agree with his other claim to have been misrepresented, or with some of his additional arguments.

(1) I apologize for the statement " and Co. Mayo", which is not correct. In listing evidence for a sedimentary origin of the Dalradian albite gneiss, Dr. Trendall (1953, p. 218) wrote: " 2 , The coincidence of the limit of the albite schists, in the south-west Highlands in particular, with stratigraphical boundaries. The albite schists are virtually confined to the Ben Ledi Grits." I wrongly assumed this to apply to their Irish equivalents in general. But my paper was concerned only with the evidence from a very small part of Scotland, and the stratigraphical position of albite schists in western Ireland would not have affected my conclusions about the Grampian Highlands albites. 